Ks. Piotr TURZYŃSKI

(Instytut Teologiczny w Radomiu, UKSW)

\title{
CIERPIENIE JAKO DROGA W UJĘCIU ŚW. AUGUSTYNA
}

W Wyznaniach, stanowiących jedną z najważniejszych ksiąg chrześcijaństwa, św. Augustyn dokonuje swoistej spowiedzi, w której jednak dominantą jest uwielbienie Boga z miłosierdziem, kierującego ludzkim życiem i historią. Nie sposób jest nie zauważyć w Wyznaniach wielkich pragnień autora, ale zarazem wielkiego cierpienia. Psychoanaliza, zastosowana do augustyńskich przeżyć, pokazuje jak bardzo mocno zapisały się cierpienia w jego pamięci i jak były żywe, determinując w mniejszym lub większym stopniu spojrzenie na całą ludzką kondycję ${ }^{1}$. Cierpienie stanie się zresztą dosyć częstym przedmiotem myśli i rozważań Hipponaty. W swojej początkowo nieuświadomionej tęsknocie za Bogiem i poszukiwaniu szczęścia, Augustyn pierwotnie odczuwa tylko dramat cierpienia i buntuje się przeciw niemu, później, po nawróceniu, zobaczy inne perspektywy i inaczej spojrzy na towarzyszący człowiekowi ból egzystencji. W życiu i myśli Doktora Łaski dokona się przemiana w podejściu do cierpienia. Obecność tematu cierpienia w refleksji świętego Augustyna nie dziwi również i z tego powodu, że męka i krzyż Syna Bożego stoją w centrum chrześcijaństwa.

\section{DOŚWIADCZENIE CIERPIENIA}

Augustyn był człowiekiem o niezwykle wrażliwej naturze, dlatego tym bardziej doświadczenie cierpienia nie było mu obce. Wspomina, że jako mały chłopiec znosił wiele przykrości w związku z nauką retoryki, o czym sam pisze:

„Boże mój, ile ja się tam nacierpiałem, ile zniosłem poniewierania, gdy nakazywano mi posłuszeństwo wobec wychowawców, którzy zachęcali mnie do kariery, jaką otworzy przede mną retoryka. Miało to zapewnić cześć u ludzi i fałszywe bogactwo. Posłano mnie do szkoły, abym poznawał nauki, których pożytek był dla mnie biedaka, zupełnie niepojęty. Ilekroć opuściłem się w pracy, brałem w skórę. Taką metodę narzucili dorośli. Wielu chłopców, któ-

\footnotetext{
${ }^{1}$ Por. F. Troncarelli, Il ricordo della sofferenza. „Le Confessioni” di sant'Agostino e la psicoanalisi, Roma - Milano 1993.
} 
rzy żyli przede mną, przeszło już tę samą ciernistą ścieżkę. Teraz ją musiałem przewędrować ja; nie dosyć jeszcze było trudu i udręki ludzkiej”’2.

Wspomnienie cielesnych kar ze szkoły pozostało wyraźne w jego pamięci: „Baty były dla mnie prawdziwą, ciężką niedolą"3. Podobnie zapisały się $\mathrm{w}$ jego pamięci momenty związane z chorobą. Była ona tak wielka, że obawa śmierci kazała mu prosić o chrzest, którego jednak nie otrzymał, co wypomina rodzicom w Wyznaniach ${ }^{4}$.

U Augustyna cierpienie jest również związane z młodzieńczym niepokojem i nieuświadomionym jeszcze pragnieniem szczęścia, które będzie się starał zaspokoić na różnych drogach. W efekcie tych młodzieńczych napięć i głębokich poszukiwań coraz dalej odchodzi on od Boga. Warto zauważyć, że im dalej odchodzi, tym bardziej cierpi, jest bardziej niespokojny i bardziej rozdarty. Czyniąc później refleksję nad swoją historią, sam zauważa, że kto nie kocha Boga, łatwo dopuszcza się zła, a tym samym cierpi jeszcze bardziej. Kto nie kocha Boga ponad wszystko, zaczyna kochać stworzenia w sposób nieuporządkowany i przesadny ${ }^{5}$. Człowiek bowiem, tracąc wolność na służbie wartości naturalnych i ziemskich z pominięciem wartości absolutnych, cierpi. O tym właśnie na podstawie własnych doświadczeń pisze Augustyn w dziele O wolnej woli:

„Każdy traci to, czego nie chciał dobrze używać, choć mógł”.

Brak autentycznej relacji z Bogiem sprawia, że największą troską Augustyna stało się mocne angażowanie w związki z ludźmi ${ }^{7}$. Byłyby one dobre, gdyby młody Augustyn nie oczekiwał od ludzi tego, czego otrzymać nie mógł. Sądził, że znajdzie szczęście w przyjaźni. Jednak po śmierci przyjaciela rozpacza, stracił wraz z nim sens i szczęście, czuje się oszukany przez życie, o czym pisał:

„Wtedy ból zamroczył moje serce ${ }^{8}[. .$.$] . Wszystko, co przedtem było nam obu$ wspólne teraz, bez niego, zmieniło się w straszną mękę"”.

Bezsilność wobec faktu śmierci i niemożność jej odwrócenia była powodem łez i cierpienia:

${ }^{2}$ Confessiones I 9, 14, CSEL 33, 12-13, thum. Z. Kubiak: Św. Augustyn, Wyznania, Kraków 1999, 35.

${ }^{3}$ Tamże, CSEL 33, 13, Kubiak, s. 36.

${ }^{4}$ Por. tamże I 11, CSEL 33, 15, Kubiak, s. 39.

${ }^{5}$ Por. S. Kowalczyk, Człowiek i Bóg w nauce św. Augustyna, Warszawa 1987, 122.

${ }^{6}$ De libero arbitrio III 18, 52, PL 32, 1296, thum. J. Domański: O wolnej woli, w: Św. Augustyn, Dialogi filozoficzne, Kraków 2001, 627.

${ }^{7}$ Por. P. Brown, Augustyn z Hippony, tłum. W. Radwański, Warszawa 1993, 181.

${ }^{8}$ Confessiones IV 4, 9, CSEL 33, 70, Kubiak, s. 92.

${ }^{9}$ Tamże, Kubiak, s. 93. 
„Nie miałem przecież nadziei, że mu przywrócę życie, i nie to było motywem moich łez. Po prostu cierpiałem, po prostu płakałem"10.

Utrata przyjaciela uświadomiła Augustynowi niebezpieczeństwo przywiązania do tego, co śmiertelne:

„Nieszczęśliwy byłem, jak nieszczęśliwy jest każdy człowiek spętany przywiązaniem do rzeczy śmiertelnych, przeżywający straszne rozdarcie, gdy te rzeczy traci"11.

Cierpienie rodzi się również, gdy w młodości, w czasie studiów w Kartaginie, oddaje się uciechom świata. Dotyka go lęk, zazdrość, gniew, chęć prowadzenia sporów, staje się podejrzliwy. Zapisał:

„Dusza moja chorowała, okryła się wrzodami i rozpaczliwie pragnęła ocierać się w świecie zewnętrznym o coraz to nowe wrażenia"12.

Równocześnie zaczyna szukać prawdy i mądrości, a błądzi po omacku:

„Nie w Bogu, lecz w stworzeniach, w sobie, i w innych szukałem radości, wzniosłości i prawdy. Tak zapadałem w cierpieniu, w pomyłki, w błędy"13.

Jest przekonany, że zstępował do piekieł i trawi go gorączka rozpaczy, bowiem szukał mądrości i nie znał prawdy ${ }^{14}$. W takiej kondycji poznaje prawdziwość twierdzenia św. Pawła: „nieszczęsny ja człowiek, bo nie czynię dobra, którego chcę, lecz zło którego nie chcę. Któż mnie wyzwoli z ciała śmierci” (Rz 7, 19-24). Wewnętrzne rozdarcie jest wielkie, gdyż obok tęsknoty za prawdą odnajduje w sobie także tęsknotę za miłością. Augustyn kocha w sposób niewłaściwy, kocha egoistycznie. Nie kocha naprawdę, lecz kocha samo kochanie ${ }^{15}$. Napięcie między tymi głębokimi tęsknotami, a tym co może zaofiarować świat, staje się źródłem olbrzymiego cierpienia jego duszy, o czym wyznaje z bólem:

„próbowałem przedzierać się ku Tobie, a Ty mnie odpychałeś, bym zakosztował śmierci. Albowiem pysznym się sprzeciwiasz ${ }^{16 "}$.

Pycha prowadziła go najpierw do manicheizmu, potem do rezygnacji i zwątpienia:

„Schłostałeś słabość mego wzroku, przemożnym we mnie uderzywszy blaskiem, aż zadrżałem z miłości i grozy. Zrozumiałem, że jestem daleko od Ciebie"17.

\footnotetext{
${ }^{10}$ Tamże IV 5, CSEL 33, 71, Kubiak, s. 94.

${ }^{11}$ Tamże IV 6, CSEL 33, 72, Kubiak, s. 94.

${ }^{12}$ Tamże III 1, CSEL 33, 44, Kubiak, s. 65.

${ }^{13}$ Tamże I 20, CSEL 33, 29, Kubiak, s. 50.

${ }^{14}$ Por. tamże III 6.

${ }^{15}$ Por. tamże III 1.

${ }^{16}$ Tamże IV 15, CSEL 33, 84, Kubiak, s. 107.

${ }^{17}$ Tamże VII 10, CSEL 33, 157, Kubiak, s. 185.
} 
Augustyn rozbudza w sobie pragnienie Boga i boi się z drugiej strony zostawić przyjemności człowieka cielesnego. Ciągle odkładał moment całkowitego oddania się Bogu, chociaż za Nim tęsknił. Zdaje sobie sprawę ze zła, które tkwi w nim samym. Jeszcze posiada ono nad nim władzę większą niż dobro, do którego się jeszcze nie przyzwyczaił. W takim stanie duszy, wypełniony cierpieniem, Augustyn prosił o Bożą interwencję: „,o jedno błagam Twoją dobroć najwyższą: nawróć mnie do siebie" ${ }^{\prime 18}$. Rośnie w nim przekonanie, że dobrze jest przylgnąć do Boga:

„Cóż może być nędzniejszego od nędzarza, który nad własną nędzą się nie lituje? Nie płacze nad sobą umarłym z braku miłości do Ciebie"19.

Zupełnie wyraźnie uznaje cierpienia jako oczyszczenie z win popełnionych. Z perspektywy swojego nawrócenia tak podsumował Augustyn czas, w którym szukał Boga:

„Dokądkolwiek człowiek chciałby pójść - jeśli nie zwróci się do Ciebie, wszędzie go dopada i przygważdża cierpienie, choćby nawet chwytał się rzeczy pięknych, ale takich, które są poza Tobą i poza jego duszą. A przecież one w ogóle by nie istniały, gdyby nie pochodziły od Ciebie" ${ }^{20}$.

Ciężka choroba w dzieciństwie, trud zdobywania wiedzy, śmierć przyjaciela, poszukiwania miłości i związek z kobietą, nadzieje związane z manichejczykami, pierwsze błędy, rozczarowania i zranienia, to wydarzenia z młodości, które zmuszały Augustyna do stawiania pytań o ludzką kondycję, a tym samym do poszukiwania odpowiedzi na problem cierpienia. Ta refleksja nad cierpieniem pozwala mu odkryć swoją małość i zarazem głębokie ludzkie tęsknoty, wśród których jest ta największa - tęsknota za Bogiem. W ten sposób cierpienie staje się drogą do poszukiwania prawdy oraz wewnętrznego pokoju, a tym samym prowadzi do odkrycia Boga.

Nie zabrakło cierpień także po nawróceniu. Augustyn chorował na płuca ${ }^{21}$ i skarżył się na ból zębów ${ }^{22}$. Jednak nieporównanie bardziej bolesnym momentem była śmierć matki. Potem z wdzięcznością pisał o matce, że bardziej cierpiała rodząc go do życia duchowego niż wtedy, gdy wydała go na świat ${ }^{23}$. Śmierć Moniki przeżywał zupełnie inaczej niż śmierć przyjaciela w młodości. Śmierć przyjaciela odbiera mu sens życia i zamyka w sobie, śmierć matki zasmuca, ale nie odbiera sensu, otwierając na nadzieję spotkania w Bogu. Sam tak wspomina to wydarzenie:

${ }^{18}$ Soliloquia I 6, NBA 3/1, 363, tłum. W. Seńko: Św. Augustyn, Solilokwia, w: Św. Augustyn, Dialogi filozoficzne, s. 244.

${ }^{19}$ Confessiones I 13, CSEL 33, 18, Kubiak, s. 41.

${ }^{20}$ Tamże IV, 10, CSEL 33, 76, Kubiak, s. 98.

${ }^{21}$ Por. tamże IX 2.

22 Por. tamże IX 4.

${ }^{23}$ Por. tamże V 9. 
„Gdy zamykałem jej oczy, spłynął z mego serca niezmierny smutek, który przelałby się obfitymi łzami, gdybym nie powstrzymywał tego płaczu rozpaczliwym wysiłkiem woli, dopóki oczy nie oschły. Ciężkie to było zmaganie"24.

W okresie pasterskiej posługi jako biskupa Hippony powodem cierpienia jest dla niego wszystko, co sprzeciwia się sprawie Pana, natomiast do radości pobudzało to, dzięki czemu powiększała się chwała Boga ${ }^{25}$. Nawrócony Augustyn cierpi również z powodu swoich dawnych grzechów, wyznając:

„Kochałem marność i szukałem kłamstwa. Jak boleśnie, jak strasznie z głębi piersi jęczałem, gdym to rozpamiętywał"26.

Praca nad sobą, pamięć poplątanej przeszłości i zmaganie się z dawnymi przyzwyczajeniami stały się dla niego wielkim ciężarem:

„Ciężko się trudzę o Panie, na tym polu, którym ja sam jestem dla siebie. Stałem się dla siebie polem kamiennym: gdy się je uprawia pot zalewa oczy"27.

Postępując w życiu duchowym coraz wyraźniej widział własną nędzę, a równocześnie coraz bardziej był rozkochany w Bogu i dostrzegał sens zbawienia dokonanego przez Stwórcę w osobie Jezusa Chrystusa:

„Przerażony moimi grzechami i brzemieniem mojej nędzy biłem się z myślami i zamierzałem nawet uciec do pustelni. Lecz zabroniłeś mi tego i umocniłeś mnie słowami: Oto za wszystkich umarł Chrystus, aby ci, którzy żyją, już nie dla siebie żyli, ale dla tego, który za nich umarł"28.

Walka duchowa między człowiekiem cielesnym a człowiekiem duchowym stała się przyczyną wielkich cierpień duchowych. W Wyznaniach pisał:

„walczyły we mnie dwie wole, dawna i nowa, cielesna i duchowa i w ich

zażartym zmaganiu roztrwoniła się moja dusza"29.

Świadomość samego siebie, obserwacja życia i umiejętność stawiania pytań oraz egzystencjalny niepokój sprawiły, że pisząc o cierpieniu jest autentyczny, wie o czym mówi i zna wagę odpowiedzi. Augustyńskie rozważania o cierpieniu nie są więc tylko słowami intelektualisty dalekiego od życia, ale raczej świadectwem kogoś zanurzonego w nasyconej cierpieniem ciała i duszy egzystencji człowieka. Osobiste cierpienia Augustyna stają się w jego refleksji cierpieniami niejako człowieka uniwersalnego.

\footnotetext{
${ }^{24}$ Tamże IX 12, CSEL 33, 223, Kubiak, s. 253.

${ }^{25}$ Por. A. Eckmann, Święty Augustyn - duszpasterz, VoxP 8 (1988) z. 14, 310.

${ }^{26}$ Confessiones IX 4, CSEL 33, 206, Kubiak, s. 236.

27 Tamże X 16, CSEL 33, 244, Kubiak, s. 280.

28 Tamże X 43, CSEL 33, 279, Kubiak, s. 317.

${ }^{29}$ Tamże VIII 5, CSEL 33, 178, Kubiak, s. 208.
} 


\section{II. ŹRÓDŁO CIERPIENIA}

Mówiąc o kondycji ludzkiej Hipponata podkreśla, że zarówno ciało, jak i dusza oraz ich połączenie pochodzą od Boga, lecz Bogiem nie są, dlatego człowiek jako stworzenie zanim powstał był nicością i sam z siebie takim pozostaje. Jest „ziemią i prochem”30. Tylko Bóg jest wieczny i niezmienny. Gdyby natomiast stworzył coś z siebie, byłby zmienny, a tego o Bogu twierdzić nie można. Świat stworzony z jednej strony uczestniczy w bycie, a z drugiej w niebycie (ex nihilo). Zmienność stworzeń dokonuje się zarówno w kierunku dobra, jak i zła, bytu i niebytu ${ }^{31}$. Człowiek jako stworzenie jest więc podmiotem zmian, czasowości i cierpienia ${ }^{32}$. Augustyńska wizja jest spójna i wyrasta z ontycznej koncepcji bytu niezmiennego. Augustyn pisze: „Byt prawdziwy nietknięty $i$ autentyczny to jedynie byt niezmienny" ${ }^{\prime 3}$, ponieważ tylko taki byt jest absolutnie prosty i tylko on jest byciem $\mathrm{z}$ istoty. $\mathrm{Z}$ zasady tej, będącej jedną z podstawowych w filozofii augustyńskiej ${ }^{34}$, wynika również twierdzenie, że byty, które nie są Bogiem, mają swoje ograniczenia, złożoność i zmienność, a to u człowieka obdarzonego rozumem i świadomością oznacza również cierpienie. Dobro stworzenia jakiegokolwiek jest zawsze względne i ograniczone. W bytach stworzonych tkwi zawsze jakaś niepełność i brak. „Zło należy jakby do ontycznego statusu stworzeń” ${ }^{35}$. Zmienność stworzenia pozwala św. Augustynowi porównać życie ludzkie do płynącej rzeki, jest ono krótkie i przemijające, jest ciągłą walką i męką, a ciąży nad nim cień śmierci ${ }^{36}$. Chyba żaden z Ojców Kościoła nie pisał tak dużo i wnikliwie o ludzkiej kondycji wypełnionej znikomością, przemijaniem i kruchością losu. Jest to jeden z ulubionych tematów kazań naszego Biskupa ${ }^{37}$. W De civitate Dei Hipponata nie waha się nazwać życia człowieka biegiem ku śmierci ${ }^{38}$. Człowiek odnajduje w sobie wielkie tęsknoty za nieśmiertelnością, szczęściem, wolnością, ale i doświadcza swoich ograniczeń, dlatego cierpi. Jest rozdarty między przeciwstawnymi aspiracjami i tęsknotami, oscyluje między wielkością i małością. Człowiek, z jednej strony jest jak każde stworzenie, z drugiej zaś jako jedyny wśród stworzeń stanowi obraz i podobieństwo Boga i dlatego w sposób niepowtarzalny i właściwy sobie, jest zawieszony pomiędzy Bogiem a ni-

\footnotetext{
${ }^{30}$ Por. Enarrationes in Ps. 144, 10.

${ }^{31}$ Por. A. Eckmann, Grzech pierworodny jako źródło cierpień człowieka u św. Augustyna, w: Grzech pierworodny, ŹMT 12, Kraków 1999, 120.

${ }^{32}$ Por. Enarrationes in Ps. 88, 2, 5.

${ }^{33}$ Sermo 7, 7, CCL 41, 75; Confessiones VII 11, 17, CSEL 33, 158.

${ }^{34}$ Por. A. Trapè, Sant'Agostino, w:, Patrologia, III, ed. J. Quasten - A. Di Berardino, Milano $1983,387$.

${ }^{35}$ Kowalczyk, Człowiek i Bóg w nauce świętego Augustyna, s. 67.

${ }^{36}$ Por. Enarrationes in Ps. 41, 6.

${ }^{37}$ Por. M. Simonetti, L'introduzione, w: Sant'Agostino, Commenti ai Salmi, Torino 1989, s. XXIII.

${ }^{38}$ Por. De civitate Dei XIII 10, CCL 48, 391-392.
} 
cością $^{39}$. Źródłem cierpienia jest również pewnego rodzaju napięcie, które rodzi się między światem zewnętrznym, w którym zanurzony jest człowiek, a jego wnętrzem. Wewnętrzność jest jednym z pryncypiów augustyńskiej filozofii i wzywa do rozpoczęcia poszukiwania mądrości i prawdy od wejścia w samego siebie ${ }^{40}$. Człowiek nie może odnaleźć Boga, dopóki nie odnajdzie samego siebie. Największą tragedią, która rodzi cierpienie, jest fakt, że człowieka ciągnie na zewnątrz, że traci kontakt z samym sobą i odchodzi daleko od siebie samego ${ }^{41}$. Augustyn pisze o swoim doświadczeniu, zwracając się do Boga w Wynaniach:

„Ty jednak wszystko słyszałeś: że wyłem z bólu serca, że ku Tobie wznosiła się moja tęsknota, oczy moje ciągle nie znajdowały światła. Bo światło było wewnątrz mnie, a ja szukałem go wokół siebie"42.

Innym czynnikiem wywołującym cierpienie jest tkwiące w naturze człowieka nienasycone pragnienie szczęścia. Augustyńska definicja szczęścia mówi, że szczęśliwy jest ten, kto posiada dobro, którego pragną ${ }^{43}$. Cierpienie jest zaprzeczeniem szczęścia, a powoduje je pozbawienie dobra. Jeśli szczęście jest zjednoczeniem, to w augustyńskiej wizji cierpienie jest rozłączeniem, brakiem jedności. Cierpienie jest ,nieprzyjemnym uczuciem podziału albo zniszczenia"44. Augustyn jest przekonany, że gdzie istnieje pragnienie, tam może być również cierpienie, bowiem pragnienie zawiedzione, czy utrata rzeczy już osiągniętej, przemienia się w cierpienie ${ }^{45}$. Niezaspokojone pragnienie jest źródłem frustracji, która z jednej strony jest cierpieniem i trudem woli, a z drugiej często staje się bodźcem i motorem rozwoju.

W samej naturze stworzonej człowieka istnieje możliwość cierpienia, ale stała się ona aktualna dopiero po grzechu pierwszych rodziców. Święty Augustyn nie dopuszcza możliwości pochodzenia cierpienia od Boga. Cierpienie weszło na świat na skutek pychy pierwszego człowieka, która posunęła go do nieposłuszeństwa wobec Boga. Augustyn, szukając odpowiedzi na pytanie, dlaczego tyle zła i dlaczego tyle cierpienia, z udręk ludzkiego życia, z nędzy i cierpień wyprowadza wniosek o istnieniu grzechu pierworodne$\mathrm{go}^{46}$. W De civitate Dei pisze:

\footnotetext{
${ }^{39}$ De natura boni I 1, PL 42, 554.

${ }^{40}$ Por. Trapè, Sant'Agostino, s. 385.

${ }^{41}$ Por. Brown, Augustyn z Hippony, s. 167.

${ }^{42}$ Confessiones VII 7, CSEL 33, 152, Kubiak, s. 180.

${ }^{43}$ De vita beata 10, CCL 29, 70-71, tłum. A. Świderkówna, w: Św. Augustyn, Dialogi filozofi-

${ }^{44}$ Por. De libero arbitrio III 23, 69, NBA 3/2, 366, Domański, s. 642.

${ }^{45}$ Por. De civitate Dei XXI 3, 2, CCL 48, 761.

${ }^{46}$ Por. Eckmann, Grzech pierworodny jako źródło cierpień człowieka, s. 118.
} czne, s. 26. 
„Pełne tylu tak wielkich cierpień życie doczesne [...] świadczy, że cały rodzaj ludzki został skazany w okolicznościach związanych z jego początkiem" ${ }^{\text {"47 }}$.

W przygodnej naturze człowieka zawsze była możliwość śmierci i cierpienia, lecz w stanie natury uprzywilejowanej przez Stwórcę w raju ta możliwość mogła nie być nigdy zrealizowana ${ }^{48}$. Hipponata będzie często podkreślał, że „śmiertelność jest kondycją ciała zwierzęcego, nieśmiertelność dobrodziejstwem Stwórcy" "49. Augustyńska nauka o grzechu pierworodnym jest odpowiedzią na zagadnienie zła i cierpienia, winy i sprawiedliwości, oraz opatrzności Bożej: pozwala ona uniknąć fatalizmu dualistycznych rozwiązań gnostyków, stoików i neoplatoników ${ }^{50}$.

Obok bytowej zmienności stworzeń, która stanowi ontyczną podstawę cierpienia, oraz grzechu pierworodnego, przyczyną cierpienia jest również grzech osobisty. Według Augustyna grzech jest nieporządkiem, przedłożeniem stworzeń ponad Stwórcę. Hipponata określa go jako chorobę duszy ${ }^{51}$. Grzechy osobiste każdego człowieka stają się również pośrednią przyczyną doczesnych utrapień. Sprawiedliwość Boża domaga się bowiem, aby były już tu na ziemi ukarane. Myśl tę odnajdujemy w komentarzu do ewangelii św. Jana:

„Niech się strzegą bicza grzechów swoich! Niewątpliwie, gdy coś cierpią z powodu swoich niegodziwości, to niech wiedzą, iż Pan uczynił bicz z powrozów i w tym celu ich upomina, żeby nie grzeszyli" ${ }^{\prime 52}$.

Jednak nawet Boża sprawiedliwość łączy się zawsze i harmonizuje z pełną miłości wolą Bożą, by zbawić człowieka. W takiej zaś optyce, cierpienie wynikające z grzechu zarówno pierworodnego, jak i osobistego, może zostać wykorzystane jako środek do najwyższego celu.

\section{SENS CIERPIENIA}

Człowiek stworzony na obraz i podobieństwo Boże jest skierowany ku Bogu, jeśli się jednak od Niego odwraca i przez grzech deformuje w sobie ten Boży obraz, cierpi. Ostatecznie łaska wszechmocnego Boga reformuje człowieka i przywraca go do pierwotnego stanu ${ }^{53}$. Cierpienie, które jest sygnałem

${ }^{47}$ De civitate Dei XXII 22, 1, CCL 48, 792, thum. W. Kornatowski: Św. Augustyn, O państwie Bożym, II, Warszawa 1977, 593.

${ }^{48}$ Por. Kowalczyk, Człowiek i Bóg w nauce świętego Augustyna, s. 88.

${ }^{49}$ De Genesi ad litteram VI 25, 36, PL 34, 354, thum. J. Sulowski, PSP 25, 232

${ }^{50}$ Por. P. Rigby, Original sin, w: Augustine through the ages. An encyclopedia, ed. A.D. Fitzgerald, Michigan/Cambridge 1999, 607.

${ }^{51}$ Por. Augustinus, In Joannis evangelium tract. 12, 2, CCL 36, 120-121, tłum. W. Szołdrski, PSP $15 / 1,184$.

${ }^{52}$ Tamże 10, 8, CCL 36, 105, PSP 15/1, 164.

${ }^{53}$ Por. G. Madec, Nawrócenie Augustyna aspekt wewnętrzny i wspólnotowy, „Życie Katolickie” 9 (1988) 23. 
jakiegoś stanu zaburzenia natury, równocześnie przy pomocy łaski Bożej leczy ze słabości woli, którą ograniczało przyzwyczajenie do ulegania życiu popędowemu ${ }^{54}$. Jednym $z$ owoców cierpienia jest nawrócenie: przez cierpienie człowiek może zmienić się na lepsze, doświadczając żywej obecności Boga. Mając na uwadze własne doświadczenia Augustyn pisze:

„Niech Cię wysławia serce me, język mój, niech wołają wszystkie kości moje. Panie któż podobny Tobie? [...] Sięgnąłeś swą prawicą aż do samej głębi mego konania. Stamtąd z głębi mego serca wydobyłeś i precz odrzuciłeś, bezmiar mojego zepsucia" ${ }^{\text {"5 }}$.

Zwłaszcza cierpienia duszy porównuje Augustyn do umierania i jest przekonany, że „Bóg przez cierpienie uczy, uderza po to, by uleczyć, zabija, abyśmy nie umarli daleko od Niego" "56. W takim ujęciu cierpienie nabiera charakteru relatywnego, staje się drogą do uzyskania wyższego celu, jakim jest zbawienie człowieka. Odkrycie zbawczej roli cierpienia pozwala człowiekowi zrozumieć, że może ono być dopuszczane przez Boga albo nawet pochodzić od Boga i być wyrazem Jego łaski i dobroci ${ }^{57}$.

Augustyn rozróżnia cierpienia cielesne i cierpienia duchowe, uważając jednak, że te drugie przewyższają trwaniem, siłą i natężeniem cierpienia cielesne. Wrażliwość duszy ludzkiej jest tak wielka, że nawet wspomnienie przebytych cierpień boli, a niebezpieczeństwo nowych napełnia duszę smutkiem i bolesnym niepokojem. W sposób szczególny cierpienia duszy owocują pokorą i każą zwrócić się do Tego, który jest Panem wewnętrznego świata:

„Cierpienia duszy były wielkimi głosami kołaczącymi do miłosierdzia Twojego" 58 .

Zwłaszcza w Homiliach na Ewangelię św. Jana cierpienie jest ukazywane najczęściej jako środek zamierzony przez Boga, aby poprawić życie człowieka: Bóg bowiem pragnie, by człowiek odwrócił się od grzechu. Cierpienie, jak lekarstwo, pojawia się w trudach życia i skomplikowanych kolejach losu ${ }^{59}$. Według Augustyna, po grzechu zawsze budzi się cierpienie i jest ono wezwaniem do odrzucenia pychy i samowystarczalności, jest więc wołaniem o po-

${ }^{54}$ Por. W. Eborowicz, Proces nawrócenia św. Augustyna, VoxP 8 (1988) t. 14, 75.

${ }^{55}$ Confessiones IX 1, CSEL 33, 197, Kubiak, s. 228.

${ }^{56}$ Tamże II 2, CSEL 33, 30, Kubiak, s. 53.

${ }^{57}$ Tamże IX 4, CSEL 33, 202, Kubiak, s. 234 i 238: „I błogo mi jest Panie, wdzięcznym sercem wspominać, jakimi to ościeniami duchowymi mnie ujarzmiłeś, jak mnie wygładziłeś, uniżywszy góry i wzniesienia moich myśli, jak wyprostowałeś moje krzywe drogi, a ostre złagodziłeś [...]. Jednego na pewno nie zapomnę i nie pominę: tego, jak surowo mnie wychłostałeś i jak zaraz potem w cudowny sposób pochyliło się nade mną Twoje miłosierdzie. Karałeś mnie wtedy dotkliwym bólem zębów".

${ }^{58}$ Tamże VII 7, CSEL 33, 152, Kubiak, s. 180.

${ }^{59}$ Por. In Joannis evangelium tract. 11, 1, CCL 36, 1. 
korę i propozycją odkrycia Boga: cierpienie bowiem kieruje ku Chrystusowi i prowokuje tęsknotę za Stwórcą. Jest ono bólem z powodu własnej nędzy i łączy się ze świadomością ogromnej miłości Boga, od której pochodzi wszystko. Biskup Hippony świadom, że dostęp do Bożego świata jest łaską, uśmierzeniem bólu i uzdrowieniem, modli się w swoich Wyznaniach:

„Udziel mi tego, co kocham, bo że kocham, Twoim jest darem. Udziel, bo podjąłem zadanie poznania Ciebie i jakże mi jest ciężko, póki nie otworzysz wrót" $"$.

Bez Boga i Jego łaski życie jest ciężarem.

Równocześnie cierpienia są próbą człowieka sprawiedliwego, środkami ćwiczenia się w cnocie, objawiają prawdę o człowieku, ujawniają jego przymioty i pomnażają zasługi szczególnie w perspektywie wieczności ${ }^{61}$. Augustyn jest przekonany, że człowiek dorasta i duchowo dojrzewa przez walkę i cierpienie $^{62}$. W liście 130 do Proby na temat modlitwy Hipponata podkreśla, że trudy i cierpienia doczesnego życia służą do uzdrowienia ludzkiego serca z pychy i z przekonania o samowystarczalności. Te cierpienia uczą także cierpliwości w oczekiwaniu na największy dar, jakim jest niebo. Są one umartwieniem człowieka i służą do tego, by wyrwać go z grzechów ${ }^{63}$.

W nauce św. Augustyna o cierpieniu widać głęboki optymizm. Wypływa on z wiary w opatrznościową opiekę Boga, który, jeśli nawet dopuszcza cierpienie, ma w tym ukryty sens i cel, a z pewnością w swojej wszechmocy potrafi wprowadzić cierpienie na wyższy poziom swojej optyki i wykorzystać je do tego, by człowieka przyprowadzić do siebie ${ }^{64}$. Augustyn jest przekonany, że to Bóg kieruje historią człowieka i trzeba się poddać Jego woli:

„Ten, kto Tobie udzielił szczęścia w tym świecie, dał ci je na twą pociechę, a nie na zepsucie. I znowu, kto chłoszcze cię w tym życiu, czyni to, aby cię poprawić, a nie potępić" ${ }^{65}$.

Cierpienie jest złem, ale zwłaszcza w dyskusji z manichejczykami Hipponata podkreśla, że nie ma zła absolutnego, z natury, dlatego Bóg jako wszechmocny może uczynić cierpienie drogą do dobra. Święty Biskup mówił często swoim słuchaczom o pedagogicznym wymiarze cierpienia i stawiał przed oczyma wyższe dobro, które ma na celu Boski Pedagog:

\footnotetext{
${ }^{60}$ Confessiones XI 22, CSEL 33, 299, Kubiak, s. 340.

${ }^{61}$ Por. W. Eborowicz, Cierpienie ludzi i cierpienie zwierzat wedlug św. Augustyna i augustynistów XVII w., SPelp 3 (1973) 247.

${ }^{62}$ Por. S. Kowalczyk, Koncepcja człowieka u św. Augustyna, SSan 1(1980) 289.

${ }^{63}$ Por. Epistula 130, 14, 25, PL 33, 820.

${ }^{64}$ Por. De vera religione 23, 44, CCL 32, 215.

${ }^{65}$ In Joannis evangelium tract. 12, 14, CCL 36, 129, PSP 15/1, 195.
} 
„Bóg więc wie, co dla nas jest pożyteczne, o to się tylko starajmy, aby serce nasze było zdrowe, a jeśli ciało chłostane jest cierpieniami, prośmy Go o pomoc. Prosił Go apostoł Paweł, aby odwrócił od niego bodziec ciała, a Bóg nie chciał usunąć. Czy go to wzburzyło, czy smucąc się mówił, iż jest opuszczony? Przeciwnie, oświadczył, iż nie jest opuszczony, bo nie zostało mu zabrane, co chciał, aby mu wzięto, aby owa słabość została uzdrowiona. Znalazł bowiem w głosie Lekarza: «Dosyć masz łaski mojej, bo moc w słabości się doskonali» (2Kor 12, 9)" ${ }^{\prime 66}$.

Przyjęcie cierpienia jako oczyszczającej chłosty jest motywem wyjątkowo często powtarzanym przez Augustyna. Bóg zna potrzeby każdego człowieka i wie, co jest dla niego korzystne. W jednej z homilii do Ewangelii św. Jana Hipponata zwraca się do swoich słuchaczy:

„W swym postępowaniu trzymaj się Pisma Boga twego i bądź spokojny. Czego Bóg nie chce, abyś cierpiał, cierpieć nie będziesz, a to, co pozwolił, abyś cierpiał, jest biczem tego, który cię chce poprawić, a nie karą potępiającego. Bracia moi, gdyby dziecko wzbraniało się przyjmować od ojca swego uderzeń i chłosty, czyż nie uważalibyśmy je za pyszne, za stracone dla ojcowskiej karności”, ${ }^{\circ}$.

Przyjęcie tej wymagającej postawy rodzi także potrzebę cierpliwości:

„W cierpieniach, jakie ktoś znosi, a nie w dobrach, jakich zażywa, potrzeba cierpliwości”68.

Św. Augustyn pochwala przyjmowanie tego, co Bóg daje, ale jednocześnie pochwala też pokorne i ufne przyjmowanie Bożej odmowy. W jego słowach słychać potrzebę zawierzenia Bogu, nawet w sytuacjach po ludzku niezrozumiałych.

Hipponata ekonomię Bożą porównuje w Homiliach na ewangelię św. Jana do działania lekarza, który zna bezpośrednio chorobę, wie jak jest niebezpieczna, i dobiera najlepsze metody, by pomóc i wyleczyć chorego. Podstawę stanowi tu idea Chrystusa Lekarza i grzechu jako choroby. Znamienny jest tekst z 7 homilii tego komentarza:

„Skąd wiesz, iż Bóg nie chce cię uzdrowić? Jeszcze potrzeba, abyś był chłostany? Skąd wiesz, jak zgniłe jest to, co lekarz wycina, używając żelaza na gangrenę? Czy nie wie, co ma czynić, do którego miejsca ma wycinać? Czy bolesny jęk operowanego powstrzymuje rękę dobrego lekarza? Ów woła, ten wycina. Czy okrutny jest ten, kto nie słyszy krzyczącego, czy raczej miłosierny, bo wycinając ranę, leczy chorego? To mówię bracia, aby nikt nie szukał czegoś poza pomocą Boga, mimo iż niekiedy dostaje chłosty Pana" ${ }^{\text {"9 }}$.

\footnotetext{
${ }^{66}$ Tamże 7, 12, CCL 36, 74, PSP 15/1, 122.

${ }^{67}$ Tamże 7, 7, CCL 36, 70-71, PSP 15/1, 118.

${ }^{68}$ Tamże 124, 5, CCL 36, 683, PSP 15/2, 372.

${ }^{69}$ Tamże 7, 12, CCL 36, 74, PSP 15/1, 123.
} 
Cierpienie zarówno w osobie Chrystusa, jak i w każdym człowieku, według Augustyna ma wymiar eschatologiczny. Nie jest ono ostatecznym przeznaczeniem człowieka, ale ma charakter czasowy. Cierpienie staje się środkiem na drodze do realizacji ostatecznych przeznaczeń człowieka. W takim ujęciu cierpienie, pozostając bólem, traci swoje ostrze, zostaje wprowadzone w pełną miłości pedagogię i ekonomię Bożą i może wprost stać się znakiem Bożej miłości i troski, która chce powrotu człowieka. Cierpienie staje się lekarstwem, które ma doprowadzić do ostatecznego szczęścia. Dlatego Augustyn nie lęka się mówić o radości cierpienia, a jest to temat charakterystyczny dla chrześcijańskich mistyków, pisząc w swoich Wyznaniach:

„Ty nie opuściłeś swojego stworzenia, jesteś w ich sercach, w sercach tych, co Ciebie wyznają, co rzucają się w Twoje objęcia i płaczą w Twoim ucisku po swych wędrówkach, jakże mozolnych. A Ty łagodnie ocierasz ich łzy, aby jeszcze obficiej je wylewali i znajdowali radość w płaczu"70.

Augustyńskie rozwiązania problemu cierpienia znajdują swoją inspirację w tekstach św. Pawła. Hipponata podkreśla, że trudy i cierpienia tego życia są ograniczone, ale mają swój koniec, są czasowe i przygotowują chwałę, która nie ma ograniczeń i końca. W uroczystość świętych Piotra i Pawła, w 410 r. w Kartaginie, świeżo po wieściach o oblężeniu Rzymu, Biskup Hippony powołując się na tekst św. Pawła: „Sądzę bowiem, że cierpień teraźniejszych nie można stawiać na równi z chwałą, która ma się w nas objawić" (Rz 8, 18), przekonuje chrześcijan, że tak jak apostołom, im też Bóg nie obiecał chwały i szczęścia ziemskiego, stąd wytrwałość w trudach życia rodzi owoc w wieczności ${ }^{71}$. Innym razem w uroczystość męczenników Augustyn porównuje życie chrześcijańskie do Bożej batalii, którą trzeba podjąć, „bowiem niewielkie utrapienia naszego obecnego czasu gotują bezmiar chwały przyszłego wieku" (2Kor 4,17$)$. Ostatecznie, na końcu, jak przy żniwach, cierpienia jak słoma odejdą, zostawiając ziarno jako owoc chwały ${ }^{72}$.

\section{CIERPIENIE SYNA BOŻEGO}

W augustyńskiej teologii dominuje problem Wcielenia, choć obecna jest także nauka o zbawieniu dokonanym przez ofiarę na krzyżu. Zbawienie dokonane przez Chrystusa, jest uwolnieniem z niewoli grzechu i starego człowieka, a dokonuje się dzięki Wcieleniu i całemu misterium paschalnemu Syna Bożego. Nauka o Chrystusie znajduje się w centrum myśli Hipponaty stając się podstawą wszystkich poszukiwań i twierdzeń ${ }^{73}$. Artykułując prawdę o tajemnicy

\footnotetext{
${ }^{70}$ Confessiones V 2, CSEL 33, 90, Kubiak, s. 113.

${ }^{71}$ Por. Sermo 296, 6, ed. G. Morin, Miscellanea Agostiniana (= MA), I, Roma 1930, 405.

${ }^{72}$ Por. Sermo 15, 4-5, MA I 139.

${ }^{73}$ Por. Trapè, Sant'Agostino, s. 410.
} 
Wcielenia, Augustyn podkreśla, że człowieczeństwo Syna Bożego jest pełne we wszystkich swoich wymiarach, także cielesnym i psychologicznym. Chrystus doświadczył wszystkich potrzeb i procesów, które są częścią ludzkiej egzystencji. On rósł, doświadczał ludzkich ograniczeń, cierpiał, był głodny, spragniony, zmęczony, płakał i umierał ${ }^{74}$. Mówiąc o cierpieniu Chrystusa, podkreśla bardzo często dobrowolną zgodę Zbawiciela na przyjęcie cierpienia i krzyża. Akceptacja męki i śmierci jest w Chrystusie wyrazem wolności i posłuszeństwa Ojcu:

„[Jezus] nie mówi poddaję się śmierci z konieczności, z powodu mego grzechu, lecz umierając, spełniłem wolę Ojca mego; więcej przy tym czynię cierpiąc, bo gdybym nie chciał, nie cierpiałbym" ${ }^{\text {"75 }}$.

„Nie cierpiałby więc, gdyby nie chciał cierpieć; gdyby nie cierpiał, Jego krew nie byłaby przelana; jeśliby owa krew nie była przelana, świat nie byłby odkupiony" ${ }^{\prime 76}$.

Cierpienie Syna Bożego i Jego przelana krew są przyczyną sprawczą odkupienia. W myśli św. Augustyna cierpienie ukazywane jest jako środek do celu, jakim jest zbawienie. Tym, co łączy całe dzieło Syna Bożego, jest Jego pokora, ujawniona zarówno we Wcieleniu, jak i na krzyżu. Pokora jest więc drogą Chrystusa prowadzącą przez uniżenie, cierpienie i śmierć do życia. W 80 homilii do Ewangelii św. Jana Hipponata staje z podziwem wobec niezwykłej wymiany, jaka dokonuje się w Chrystusie: przyjmuje On od nas cielesność i śmierć, aby dać nam życie ${ }^{77}$. Jako Bóg - Człowiek został dwukrotnie wywyższony: na krzyżu i w chwale. Według św. Augustyna „należało, aby wywyższenie uwielbienia poprzedziło poniżenie męki"78. Pokorne przyjęcie śmierci przez Chrystusa, otworzyło dla nas drogę do niebieskiej ojczyzny:

„Dlaczego Pana ukrzyżowano? Albowiem potrzebne ci było koniecznie drzewo jego pokory. Pychą byłeś nadęty i daleko od owej ojczyzny byłeś odrzucony, a fale tego świata przerywały ci drogę; nie zdołasz nią dostać się do ojczyzny, jeśli drzewo [Krzyża] nieść cię nie będzie"79.

Naśladowanie pokornego Zbawiciela staje się drogą każdego, kto w Niego wierzy, a drzewo krzyża jest umocnieniem na tej drodze:

„Ciebie zaś, który jak On po morzu chodzić nie możesz, niech okręt niesie, niech drzewo dźwiga. Wierz w Ukrzyżowanego, a dojść zdołasz. Dla ciebie

\footnotetext{
${ }^{74}$ Por. Epistula 137, 8-9, PL 33, 876.

${ }^{75}$ In Joannis evangelium tract. 41, 7, CCL 36, 361, PSP 15/1, 496-497; zob. tamże 48, 8, CCL $36,417$.

${ }^{76}$ Tamże 37, 10, CCL 36, 338, PSP 15/1, 466.

${ }^{77}$ Por. tamże 80, 3, CCL 36, 529.

${ }^{78}$ Tamże 51, 9, CCL 36, 442, PSP 15/2, 59.

${ }^{79}$ Tamże 2, 4, CCL 36, 13-14, PSP 15/1, 43.
} 
został ukrzyżowany, aby pokory nauczyć, bo gdyby przybył jako Bóg, nie byłby uznany" $"$.

Według św. Augustyna „nie ma innej drogi dla pychy upadłego człowieka, jak powtórzenie pokory Chrystusa i naśladowanie Go w tym, co przeżył" ${ }^{\prime 1}$. Warto zauważyć, że w swoich wczesnych dziełach nasz Biskup ujmuje Chrystusa jako nauczyciela i przykład dotykający ludzkiego rozumu i woli, w późniejszym zaś okresie będzie podkreślał, że cierpienie i krzyż Chrystusa pozwalają lepiej zrozumieć ludzkie cierpienia oraz leczą wewnętrzny nieporządek i chaos pragnień ${ }^{82}$. Dzieło Chrystusa ma nie tylko wymiar indywidualny, ale również eklezjalny i determinuje całą historię ludzkości. Jeśli augustyńska wizja historii jest walką między dwoma państwami, tzn. między państwem ziemskim a civitas Dei, to zwycięstwo królestwa, którego zasadą jest miłość Boga i miłość bliźniego, dokonuje się na drodze pokory i cierpienia:

„Królestwo, które nie było z tego świata, pokonało pyszny świat nie okrutną walką, lecz pokornym cierpieniem" $"$.

W swym traktacie De Trinitate Hipponata wyjaśnia, że śmierć i zmartwychwstanie Chrystusa są sacramentum et exemplum naszej podwójnej śmierci: duchowej i cielesnej oraz zmartwychwstania człowieka zewnętrznego i wewnętrznego ${ }^{84}$. Wynika z tego, że cierpienie Chrystusa i Jego ofiara nie jest tylko modelem, według którego należy kształtować życie, ale w tej ofierze i cierpieniu są nasze cierpienia, a Chrystus cierpiący i umierający jest sakramentem ${ }^{85}$ tych ofiar, a równocześnie przyczyną sprawiającą, iż mogą one dotrzeć do Boga Ojca i podobać się Jemu ${ }^{86}$. O tym zawieraniu się cierpień ludzkich mówi często Augustyn, zwłaszcza przy okazji tematów eklezjologicznych. W jego koncepcji „całego Chrystusa” (Christus totus), którym jest Kościół składający się z Głowy i Ciała, gdy cierpi Chrystus na krzyżu, cierpi

${ }^{80}$ Tamże, CCL 36, 14, PSP 15/1, 44.

${ }^{81}$ A. Eckmann, Symbol apostolski w pismach św. Augustyna, Lublin 1999, 169.

${ }^{82}$ Por. W. Mallard, Jesus Christ, w: Augustine through the ages. An encyclopedia, coll. 465.

${ }^{83}$ In Joannis evangelium tract. 116, 1, CCL 36, 647, PSP 15/2, 328.

${ }^{84}$ Por. De Trinitate IV 3, 6, CCL 50, 170: „Una ergo mors nostri Salvatoris duabus mortibus nostris saluti fuit. Et una eius resurrectio duas nobis resurrectiones praestitit cum corpus eius in utraque re, id est et in morte et in resurrectione, et in sacramento interioris hominis nostri et exemplo exterioris medicinali quadam convenientia ministratum est"; zob. thum. M. Stokowska, POK 25, 179-180; S. Poque, L'introduction, les notes et la traduction, w: Augustin, Sermons sur la Pâque, SCh 116, Paris 1966, 14-15.

${ }^{85}$ Por. Enarrationes in Ps. 74, 12, CCL 39, 1034: „Sacrificium victimarum et pecorum magnum habet sacramentum; sed in omnibus illis generibus sacrificiorum intellegitur unum illud sacrificium et unica victima, in cruce Dominus; pro quibus omnibus sacrificiis unum nos habemus, quia et illa figurabant haec, illis haec figurabantur", thum. J. Sulowski, PSP 39, 337.

${ }^{86}$ Por. J. Lécuyer, Le sacrifice selon saint Augustin, w: Augustinus Magister, II, 909; B. Studer, „Sacramentum et exemplum” chez saint Augustin, RechAug 10 (1975) 87-141. 
też Kościół, gdy dzisiaj cierpi Ciało Chrystusa w swoich członkach, a przede wszystkim w męczennikach, cierpi też Chrystus ${ }^{87}$. Współcierpienie członków Ciała Chrystusa wyjaśnia także cytując słowa św. Pawła:

„«Teraz raduję się w cierpieniach za was i dopełniam na ciele moim tego, czego nie dostaje cierpieniom Chrystusa» (Kol 1,24). Nie powiedział: «moim cierpieniom», lecz Chrystusa, bo był członkiem Chrystusa. I w cierpieniach, jakie Chrystus na całym ciele ponosić musiał, on też Jego cierpienia według swej miary uzupełniał"s8.

Cierpienie w ujęciu Hipponaty jest też służbą i obowiązkiem tych, którzy związali się z Chrystusem. Uczy on o specjalnej powinności podjęcia cierpienia przez pasterzy Kościoła na wzór Dobrego Pasterza:

„Jeśli dobry pasterz oddał swe życie za owce swoje i ze swych owiec tak wiele uczynił męczenników, to o ileż bardziej, aż do poniesienia śmierci za prawdę i przeciw grzechowi, aż do przelania krwi winni walczyć ci, którym (Pan) je powierzył, aby je paśli, nauczali i rządzili" ${ }^{\circ 9}$.

Augustyn jest przekonany, że w każdym chrześcijaninie powinna dokonać się droga Chrystusa, która prowadzi przez cierpienie do chwały, dlatego zachęca: „kto chce żyć, niech teraz cierpi na ziemi, aby potem królować w niebie" ${ }^{90}$. Cierpiący Chrystus stał się naszą drogą, Hipponata zaś lubi używać tego obrazu drogi ${ }^{91}$. W chrystologii augustyńskiej dopełnieniem obrazu drogi jest obraz ojczyzny, w ten sposób obydwa odnoszą się odpowiednio do człowieczeństwa i bóstwa Chrystusa ${ }^{92}$. Jezus Chrystus jako Syn Boży Wcielony posiada podwójną funkcję: Ojczyzny i Drogi, czyli z jednej strony konstytuuje cel ludzkiej egzystencji ${ }^{93}$, z drugiej zaś jest również środkiem, który prowadzi do tego celu. W tych obydwu funkcjach Chrystus stanowi równocześnie prawdę o wieczności i o czasie oraz o moście łączącym obie te rzeczywistości:

„Jeśli utkwimy wzrok w Chrystusie nie zabłądzimy błąkając się bez celu, ponieważ On jest prawdą ku której zmierzamy i drogą po której idziemy"94.

${ }^{87}$ Por. Epistula 140, 6, 18, CSEL 44, 169: „Ecclesia in illo (Christi) patiebatur quando pro Ecclesia Christus patiebatur. Sicut etiam in Ecclesia patiebatur, quando pro illo Ecclesia patiebatur"; In Joannis evangelium tract. 52, 1, CCL 36, 446: „Nos in se transtulit, nos in se suscepit caput nostrum, membrorum suorum suscepit affectum".

${ }^{88}$ In Joannis evangelium tract. 108, 5, CCL 36, 617-618, PSP 15/2, 290.

${ }^{89}$ Tamże 123, 5, CCL 36, 680, PSP 15/2, 368.

${ }^{90}$ Tamże 13, 11, CCL 36, 136, PSP 15/1, 204.

${ }^{91}$ Por. Sermo 124, 3, PL 38, 685; Sermo 141, PL 38, 777.

${ }_{92}$ Por. Sermo 91, 7, PL 38, 571; Sermo 92, 3, PL 38, 573; zob. L. Galati, Cristo la via nel pensiero di S. Agostino, Roma 1956; G. Madec, La Patrie et la voie. Le Christ dans la vie et la pensée de Saint Augustin, Paris 1989.

${ }^{93}$ Por. Enarrationes in Ps. 149, 1, CCL 40, 2178: „Vita aeterna ipse Christus est”.

${ }^{94}$ Tamże 84, 2, CCL 39, 1162, PSP 40, 74. 
Drogą do chwały jest człowieczeństwo Chrystusa, a jeszcze bardziej konkretnie, to co jest istotną charakterystyką człowieka, cierpienie. W Chrystusie człowieczeństwo i cierpienie konstytuują pewną drogę do chwały nieba.

$$
* * *
$$

Augustyn z własnego doświadczenia zna różnorodność cierpienia, jego ciężar i dramat. Cierpienie stało się dla niego wezwaniem do poszukiwania najistotniejszych wartości życia i ostatecznie pomogło mu odkryć Boga. Opisany w Wyznaniach proces przemiany i nawrócenia dotyka także spojrzenia na znaczenie i wartość cierpienia. Po nawróceniu Augustyn dostrzeże w cierpieniu korekcyjną rękę Boga, a zarazem możliwość przewartościowania. Cierpienie jest dla niego konsekwencją złożoności ludzkiego bytu i stanowi kondycję bytu stworzonego ex nihilo. Intensywne i bardzo bolesne cierpienia duszy są, według Augustyna, rezultatem niezaspokojonych w człowieku pragnień miłości, prawdy i szczęścia. Pragnienia te umieścił w człowieku sam Stwórca, stwarzając go na swój obraz i podobieństwo. To napięcie między tym, czego się pragnie, a niemożliwością całkowitego spełnienia na ziemi rodzi ból. Cierpiętliwość była w ogrodzie rajskim zablokowana nadzwyczajną łaską, natomiast została zaktualizowana po grzechu pierworodnym. Augustyn podkreśla, że źródłem cierpień są często grzechy osobiste człowieka, które są przedkładaniem rzeczy tego świata nad Boga. W ujęciu Augustyna, cierpienie, nie tracąc swojego bólu, nabiera sensu jako lekarstwo, które ma uzdrowić duszę skoncentrowaną na sobie i zapominającą o Bogu. Cierpienie nabiera w ten sposób niejako pozytywnego znaczenia, jest drogą powrotu do siebie, do Boga i Jego porządku. Augustyn podkreśla, że cierpienie jest także próbą i oczyszczeniem sprawiedliwych: będąc sytuacją graniczną, objawia człowiekowi prawdę o nim samym. W Chrystusie cierpienie odsłania swój zbawczy sens, bo staje się źródłem zbawienia dla całego świata. Opatrzność Boża ogarniając z miłością człowieka w tajemnicy Wcielenia i Paschy Chrystusa sprawia, że cierpienie zostaje wkomponowane w cały plan zbawienia i staje się drogą do zmartwychwstania. Człowieczeństwo i cierpienia Chrystusa na krzyżu otwierają równocześnie drogę wszystkim ludzkim cierpieniom, aby połączone w Synu Bożym Wcielonym dotarły do Boga. U Augustyna cierpienie nie ma charakteru absolutnego i ostatecznego, jest ono dopuszczane przez Boga i wykorzystane przez Niego, aby sprowokować człowieka do przewartościowań i nawrócenia. W ten sposób staje się ono drogą do tego, co najważniejsze i ostateczne. 


\section{LA SOFFERENZA QUALE VIA NEL PENSIERO DI SANT'AGOSTINO}

\section{(Riassunto)}

Agostino conosce bene le sofferenze dell'uomo. Le ha sperimentato sin da bambino. Riconosce le sofferenze del corpo e le sofferenze dell'anima. Nelle Confessioni egli descrive la sua conversione nella quale si cambia anche il suo sguardo sulla sofferenza. Prima si ribella contro il dolore e poi riconosce il suo valore salutare. Secondo il Vescovo d'Ippona la sofferenza è il risultato della complessità dell'essere umano e della sua creazione ex nihilo. Dio, creando uomo sulla sua immagine e somilianza, ha messo nel suo cuore il desiderio dell'amore, della verità e della felicità. Questi profondi desideri non possono essere appagati pienamente sulla terra, allora uomo prova la sofferenza. Nel paradiso questa condizione era arrichita dal dono speciale, perciò primi uomini non hanno sofferto. Con il peccato originale entra nella vita umana la sofferenza. Anche i peccati personali sono spesso la causa delle sofferenze. Agostino sottolinea tuttavia, che la Provvidenza Divina fa entrare la sofferenza nel piano della salvezza e il dolore diventa un stimolo alla conversione, una via verso le cose più grandi. Per i giusti la sofferenza diventa anche una prova e la purificazione. In Cristo, nella sua croce, la sofferenza acquista un valore particolare. La sofferenza e la morte di Cristo è la causa della nostra salvezza. Nel mistero del Cristo totale le sofferenze umane aggiungono il mondo divino e unite con Cristo Salvatore diventano via della salvezza. Secondo Agostino la sofferenza in Cristo, pur non perdendo la sua amarezza, aquista un valore positivo. 
